\title{
The beginnings of museology
}

\author{
Milan Popadić
}

Milan Popadić, PhD, Associate Professor

The University of Belgrade

Faculty of Philosophy

Department of Art History

18-20 Čika Ljubina Street, Belgrade, 11000

Republic of Serbia

e-mail: milan.popadic@f.bg.ac.rs

Mureológia a kultúrne dedičstvo, 2020, 8:2:5-16

DOI: $10.46284 / \mathrm{mkd} .2020 .8 .2 .1$

The beginnings of museology

In this paper, we deal with the beginnings of museology, trying to find the common origin of its many contemporary offspring. Rather than define museology, we aim to discuss the idea of museology. We assume that beneath the diverse manifestations of museology one can see today, there is a common root and we call this root the idea of museology. Based on examples tracing the history of other scientific disciplines, in this paper we track two developmental stages in the field of museology: the development from an idea to professional knowledge, and the development from professional knowledge to academic discipline. By these means, we aim to establish some of the crossing points in the progress of museology as a science.

Keywords: museology (idea, history, discipline), beginnings, museum studies, history of science

\section{Introduction: Constant beginnings}

If there were a competition for the most popular quote about museology, the following quote, from 1883, would be a very serious candidate:

If somebody spoke about museology as a science thirty or twenty years ago, he would have encountered a compassionate or contemptuous smile. Now, of course, it's different. Museums existed then, as today, though certainly not always in their present form, equipment and use. It is sufficient to note that they gradually developed from the cabinet of curiosities of the fifteenth and sixteenth centuries into the systematically organized institutions of our time . ${ }^{1}$

It is from a well-known introductory text from the Zeitschrift für Museologie und Antiquitätenkunde sowie verwandte Wissenschaften Journal of Museology and Antiquarianism as well as related sciences], No. 15, 1883. But where might one encounter this quote? Zeitschrift für Museologie und Antiquitätenkunde was published in Dresden by Johann Georg Theodor Grässe (1814-1885), a

\footnotetext{
${ }^{1}$ GRÄSSE, Johann Georg Theodor. Die Musologie als Fachwissenschaft. In: Zeitschrift für Museologie und Antiquitätenkunde sowie verwandte Wissenschaften, Vol. 15, 1883, p. 1. "Wenn jemand vor dreissig, selbst vor zwanzig Jahren von der Museologie als einer Fachwissenschaft gesprochen oder gescliriehen hätte, würde er bei vielen Personen einem mitleidigen, geringschätzenden Lächeln begegnet sein. Jetzt freilich ist diesanders. Museen existierten damals natürlich ebenso wie heute, wenn auch nicht immer in ihrer jetzigen Gestalt, Ausstattung und Benutzung. Es bedarf keiner nähern Auseinandersetzung, wie sich dieselbe nach und nach aus den Kuriositätensammlungen des 15 . und 16. Jahrhunderts zu den systematisch gegliederten Instituten der Jetztzeit entwickelt haben, wir wollen nur darauf hinweisen".
} 
cultural historian and museum expert, from 1878 to $1885 .{ }^{2}$ It is unlikely a modern reader would encounter this quote while browsing the original journal, even though it has been digitised and is today available online. ${ }^{3}$ One is more likely to come across it in other people's writings: for example, Zbyněk Zbyslav Stránský in the 1960s, Evzen Schneider in the 1970s, Lynne Teather in the 1980s, and Peter van Mensch or Ivo Maroević in the 1990s. ${ }^{4} \mathrm{It}$ is also cited in publications of the twenty-first century. ${ }^{5}$ Why is this quotation so popular?

Is it because the concept of museology as a science could not be reliably established throughout the indicated period? If so, can one talk about museology as a science at all? It is somewhat frustrating to even need to discuss such a question, since museology has been recognised, one way or another, as a discipline within the philosophy and history of science for well over a century and a half. ${ }^{6}$ In the above quotation, it is noticeable that a direct connection is established with the "cabinet of curiosities", which Grässe refers to as the forerunner of the museum. The text suggests that it is possible to talk about museology as a "special science" precisely because museums became the "systematically organized institutions of our time". In other words, the basic premise of this nineteenth-century determination is clear: museology is the science of museums. Nevertheless, it was precisely this definition that was constantly being reconsidered during the twentieth century. If, in the first half of that century, museology was seen as one of the disciplines concerned with spreading and promoting knowledge ${ }^{7}$, the second half of the century brought a sharp division between museology as the "science of museums" and museology as the "science of museality" (that is, the science of "the relationship between man and his reality"). ${ }^{8}$ This second stream ultimately led to a contemporary understanding of museology as a science of heritage ${ }^{9}$, sometimes referred to by the newly coined term

\footnotetext{
${ }^{2}$ See ANANIEV, Vitalij Gennadievič and METELKIN, Evgenij Nikolaevič. I. G. T. fon Grasse i ego rol' v razvitii muzeologii, vtoroj poloviny XIX v [I. G. T. von Grässe and his role in the development of museology in the second half of the nineteenth century]. In: Voprosy muzeologii, vol. 12, 2015, is. 2, pp. 17-21. [In Russian].

3 https://www.europeana.eu/portal/en/record/9200143/BibliographicResource_2000069469470.html; accessed 31 March 2019.

${ }^{4}$ STRÁNSKÝ, Zbyněk. Pojam muzeologije [The Concept of Museology]. In: Muzeologija, 1970, 8, p. 5 in Croato-Serbian; translation from the International Seminar on Museology held in Brno, 1969. SCHNEIDER, Evzen. La voie du musée, exposition au musée Morave. In: Museum, 1977, vol. 29, is. 4, p. 183; TEATHER, Lynne. Museology and its traditions: The British experience, 1845-1945, PhD thesis, University of Leicester, 1983, p. 2; MENSCH, Peter van. Towards a methodology of museology, PhD thesis, University of Zagreb, 1992, note 2.

${ }^{5}$ LOCHER, Hubert (ed.) Museen als Medien - Medien in Museen. Perspektiven der Museologie. Munchen: Müller-Straten, 2004, p. 110; SMEDS, Kerstin. Museum science? In: Nordisk Museologi, 2018, 1, p. 154.

${ }^{6}$ See DIXON, Roland B. Some Aspects of North American Archeology. In: American Anthropologist, New Series, vol. 4, 1913, 15, pp. 573-574; SARTON, George. Introduction to the History and Philosophy of Science (Preliminary Note). In: Isis, vol. 1, 1921, 4, p. 29. See also DESVALLÉES, André and MAIRESSE, François. Sur la muséologie. In: Culture \& Musées, 2005, 6, pp. 131-155.

${ }^{7}$ SARTON, Introduction to the History..., p. 29.

8 "Certains chercheurs, surtout d'Europe centrale, privilegient une vision plus large et plus theorique de la museologie. ... L'objet de la museologie n'est plus le musee mais la 'musealite', une relation specffique de l'homme avec la realite, relation qui est ti la fois connaissance et jugement de valeur: elle conduit a selectionner des objets qu'elle juge dignes d'etre conserves indefiniment et transmis a la societe future. Ainsi definie, la 'musealite' semble correspondre en frangais au concept de patrimoine ou de ce qu'on pourrait appeler la 'patrimonialite'.' GOB, André and DROUGUET, Noémie. La muséologie. Histoire, développements, enjeux actuels. 4e édition. Paris: Édition Format Kindle de Armand Colin, 2014.

${ }^{9}$ MAROEVIĆ, Ivo. Introduction to Museology: The European Approach. Munich: Vlg. Dr. C. Müller-Straten, 1998.
} 
"heritology". ${ }^{10}$

Bearing in mind these premises, in this paper we deal with the beginnings of museology, trying to find the common origin of its many contemporary offspring. In seeking the "beginnings" of the discipline, we take Gadmer's lead in seeking the "knowledge of things in their youth" which various outcomes and manifestations are possible. In other words, we are not aiming to define museology, but rather to discuss the idea of museology. We assume that beneath the diverse manifestations of museology one can see today there is a common root and we call this root the idea of museology. Based on examples tracing the history of other scientific disciplines, in this paper we track two developmental stages: the development from an idea to professional knowledge, and the development from professional knowledge to academic discipline. By these means, we aim to establish some of the crossing points in the progress of museology as a science.

\section{From idea to Fachwissenschaft}

An overview of contemporary definitions applied to the term "museology" throws up as many as five meanings. The first is that it refers to anything that concerns museums. The second meaning, commonly applied in Western Europe, recognizes museology as the science of museums, covering the history of museums, their social role, their organisation, and all issues pertaining to research, preservation, dissemination and so on. The third definition points to the way museology has been widely understood in Central and Eastern Europe since the 1960s: as a field of scientific research that examines the relationship between man and his reality, with museums being only one manifestation of that relationship. The fourth, or "newmuseological" meaning, which dates from the 1980s, emphasises the social role of the museum and its interdisciplinary character, along with new forms of expression and communication. Finally, the fifth definition incorporates all the previous ones and represents museology as a broad field of research in the domain of theoretical and critical thinking about the relationship between man and his reality, expressed through the documentation of reality that can be objectified. $^{12}$

The question thus arises: do these "versions" of museology have a common beginning? It is possible to speak about the beginnings of museology in various ways. It has become commonplace to say that the "father of museology" is Samuel Quiccheberg (1529-1567) ${ }^{13}$, though some ascribe this role to his contemporary, Ulisse Aldrovandi (1522-1605). ${ }^{14}$ On the other hand, as far as current research has uncovered, the term museology was first recorded

\footnotetext{
${ }_{10}$ ŠOLA, Tomislav. Towards a possible definition of museology. Paper presented at the ICOFOM Annual Conference. Paris: ICOFOM, 1982.

${ }^{11}$ GADAMER, Hans-Georg. The Beginning of Philosophy. London: Bloomsbury Academic, 2000, pp. 9-18.

${ }^{12}$ DESVALLÉES, André and MAIRESSE, François. (eds). Key Concepts of Museology. Paris: Armand Colin, 2010, pp. 53-56.

${ }^{13}$ These statements are repeated throughout the twentieth century: See MURRAY, David. Museums, their history and their use. Glasgow: J. MacLehose, 1904, p. 28; STRÁNSKÝ, Pojam muzeologije.., pp. 5-6; WAIDACHER, Friedrich. Handbuch der Allgemeinen Museologie. Wien: Böhlau, 1999, p. 84.

${ }^{14}$ ROMANO, Marco, CIFELLI, Richard and VAI, Gian Battista. Natural history: first museologist's legacy. In: Nature, 2015, 517, p. 271; HAXHIRAJ, Marinela. Ulisse Aldrovandi. Il museografo. Bologna: Bononia Univerity Press, 2016.
} 
in $1839^{15}$. Yet even before that, the terms Museum museorum $(1704)^{16}$ and Museograbia $(1727)^{17}$ were used. And in the twentieth century, several "initial" years of the discipline are mentioned, for example, International Conference in Madrid organised by the International Museums Office (IMO) in $1934^{18}$ and the establishment of ICOFOM, the International Committee for Museology of the International Council of Museums (ICOM) in 1977. To some, especially in Central Europe, Z. Z. Stránský is recognized as "the pioneer of contemporary museology" 19. To these starting points we could add other examples of local origins (for example, in the Mediterranean region, Western/Eastern Europe, the USSR or the USA). It is clear that some of these "beginnings" are metaphorical, some symbolic, some disciplinary, some institutional and some geographical. But for now, we will take the patrimonial approach and consider briefly the two alleged "fathers of museology".

In the sixteenth century, a book was published that was to become known as "the first museum treatise" and its author as the "father of museology". Entitled Inscriptiones vel tituli Theatri amplissimi, complectentis rerum universitatis singulas materias et imagines eximias etc. ${ }^{20}$ it was written by a Belgian doctor and librarian at the Bavarian court called Samuel Quiccheberg (1529-1567). A comprehensive translation of the title page illustrates its descriptiveness:

Inscriptions or Titles of the Most Ample Theatre That Houses Exeplary Objects and Exceptional Images of Entire World, So That One Could Also Rightly Call It A: Repository of artificial and marvellous things, and every rare treasure, precious object, construction, and picture. It is recommends that these things be brought together here in theatre so that by their frequent viewing and handling one might quickly, easily, and confidently be able to acquire a unique knowledge and admirable understanding of things. ${ }^{21}$

Quiccheberg's book is, in essence, a guide to arranging a collection. Close to the Bavarian court, its author had in mind the collection of Albrecht V. However, it is not an instruction for arranging a specific collection, but rather strives to offer more general, even universal solutions - bearing in mind the perspective of the time to which it belongs. It is important to point out that Quiccheberg does not claim that this is a work of specific science or discipline, but that "there is not a single discipline under the sun, nor a skill, which would not seek for its own means of performing the prescribed arrangement". 22 Another "father figure", Ulisse Aldrovandi (1522-1605), was an Italian naturalist, and also a "professor, physician, botanist, collector, philosopher, critic, mathematician, bibliophile, advisor to the Grand Duke of

\footnotetext{
${ }^{15}$ AQUILINA, Janick Daniel. The Babelian Tale of Museology and Museography: a history in words. In: Museology: International Scientific Eletronic Journal, 2011, 6, p. 1-20.

${ }^{16}$ VALENTINI, Michael Bernhard. Museum Museorum, oder vollständige Schau-Bühne aller Materialien und Specereyen, nebst deren natürlichen Beschreibung. Franckfurt am Mayn :In Verlegung Johann David Zunners,1704; accessed 31 March 2019, https://www.biodiversitylibrary.org/item/30610\#page/3/mode/1up.

${ }^{17}$ NEICKELIUS, Caspar Friedrich. Museograpbia oder Anleitung zum rechten Begriff und nützlicher Anlegung der Mvseorvm Oder Raritaten-Kammern. Leipzig: Hubert, 1727; accessed 31 March 2019, https://reader.digitale-sammlungen.de/ resolve/display/bsb10051211.html

${ }^{18}$ The International Museums Office (IMO) / Office International des Musées (OIM) was founded in Paris by the League of Nations in 1926.

${ }^{19}$ WAIDACHER, Handbuch der Allgemeinen Museologie..., p.14.

${ }^{20}$ QUICCHEBERG, Samuel. Inscriptiones vel tituli Theatri amplissimi, complectentis rerum universitatis singulas materias et imagines eximias etc. Monachii: Adamus Berg, 1565. Accessed 31 March 2019, from the Österreichische Nationalbibliothek website: http://data.onb.ac.at/ABO/\%2BZ178696704.

${ }^{21}$ MEADOW, M. A. (ed.), The First Treatise on Museums. Samuel Quiccheberg's Inscriptiones, 1565. Los Angeles: Getty, 2013, p. 61.

${ }^{22}$ MEADOW, The First Treatise on Museums..., p. 74.
} 
Tuscany and numerous Italian and French collectors". He was praised for "the vastness of his erudition and his naturalistic collection [and] the quality, the organicity and the originality of his thought in the panorama of modern museography". ${ }^{23}$ In 1603, Aldrovandi dictated this testament, which is today recognized as "a remarkable and inspiring manifesto of scientific museology". ${ }^{24}$ Similarly to Quiccheberg's text, he wrote about systems for arranging an ideal collection $^{25}$, although he was focused on presenting a natural collection rather than a universal one. Certainly, this work offers a sixteenth-century understanding of the concept of science, from an age where there the modern division of disciplines did not yet exist. As such, it presents the idea of comprehensive knowledge based on correspondence and similarity and, therefore, on special analogous classifications and taxonomies in the service of an ample understanding of the world. ${ }^{26}$

A similar approach was still prevalent in the seventeenth century. ${ }^{27}$ The first half of the eighteenth century, specifically 1727, saw the publication of an interesting edition in German under the title Museographia oder Anleitung zum rechten Begriff und nützlicher Anlegung der Mvseorvm Oder Raritäten-Kammern [Museography or Guide for the Proper Understanding and Useful Creation of Museums and Chambers of Rarities]. ${ }^{28}$ As far as is known, this was the first documented use of term museography, which is still in use today (though with changed connotations). The book's author was Kaspar Friedrich Jencquel, a Hamburg merchant, but his pseudonym, Caspar Friedrich Neickelius, appears on the front page. In a wide-ranging book of 492 pages, the first three chapters list and describe more than a hundred "repositories" (Behältnisse) which existed at that time, as well as libraries and collections of objects that had already been disbanded. The fourth chapter of the book gives instructions for decorating a chamber of rarities, founded on theoretical conclusions based on the examples described in the preceding chapters. However, what is especially interesting about this book is that, beside its author, another figure appears: the commentator, Wrocławian doctor Johan Kanold. A knowledgeable expert on the topics that Nickelius writes about, Kanold was hired by the publisher to review the author's claims in the book. Indeed, in the preface of the book, Kanold emphasizes Nikelius' "illiteracy and dilettantism" and then, in the edition itself, he corrects and complements the author's descriptions, apparently determined to make the book at least acceptable for the concerned reader ${ }^{29}$. This curiosity points to the popularity of the topic in the wider social ("commercialdilettante") circles, but also to the care taken by experts with knowledge of the field to prevent it from being degraded. ${ }^{30}$

\footnotetext{
${ }^{23}$ HAXHIRAJ, Ulisse Aldrovandi..., back cover.

${ }^{24}$ ROMANO, Natural history..., p. 271.

${ }^{25}$ Regarding Aldrovandi's collection see L'Erbario di Ulisse Aldrovandi: Una collezione di piante essiccate del XVI secolo, accessed 31 March 2019, http:/ / botanica.sma.unibo.it.

${ }^{26}$ GREENHILL, Eileen Hooper. Museums and the Shaping of Knowledge. London - New York: Routledge, 1992, pp. 89-91.

${ }^{27}$ See IMPEY, Oliver and MACGREGOR, Arthur (eds.). The Origins of Museums: The Cabinet of Curiosities in Sixteenth and Seventeenth Century Europe. Oxford: University Press, 1985.

${ }^{28}$ NEICKELIUS, Museographia oder Anleitung.

${ }^{29}$ See GOEING, Anja-Silvia. Mapping curiosity: Kaspar Friedrich Jencquel's Recommendations for Visits of Cabinets in Europe (1727), accessed 31 March 2019, https://curiositas.org/mapping-curiosity-kaspar-friedrich-jencquels-recommendations-for-visits-of-cabinets-in-europe-1727.

${ }^{30}$ However, the beginning of truly studious research into this topic had to wait for the beginning of the twentieth century. Cf. SCHLOSSER, Julius von. Die Kunst- und Wunderkammern der Spätrenaissance: ein Beitrag zur Geschichte des Sammelwesens. Leipzig: Klinkhardt \& Biermann, 1908.
} 
The changes in the intellectual, cultural and social climate in the late eighteenth to early nineteenth century, which brought to fruition both capital philosophical concepts and brutal revolutionary acts of decapitation, also caused a change of attitude towards the past and its remains. Interest in rarity and curiosity seem to have been lost under the pressures of enlightenment rationality ${ }^{31}$. But here we suggest another possible reason why this happened: the concepts of rarity and curiosity gave way to the idea of heritage, embodied in the forms and objects of the "past", especially those which were considered unusual in contemporary society. The idea of heritage as a public/national good meant that in the eighteenth and nineteenth centuries museums, the displeys that formerly belonged to private collections and now exposed on newfound altars of the nation, became spaces open to the public and thus the object of wider interests. ${ }^{32}$ In the meantime, the term museology appeared, indicating the need to reflect on the role of the museum. As mentioned above, as far we know today, the term museology was first recorded in 1839, in German, in the title of Georg Rathgeber's book, Aufbau der Niederländischen Kunstgeschichte und Museologie [The Arrangement of the Dutch History of Art and Museology]. ${ }^{33}$ In fewer than two hundred pages, the author offers a method of classifying an array of art collections within a museum. It is worth mentioning the connection of museology with the then young discipline of art history. ${ }^{34}$ From that time, museology and art history were be intertwined in order to make the past "visible and legible". 35

\section{Museology as an academic discipline}

There are, of course, many disciplines whose research objectives lie in the study of forms and objects inherited from the past. Archaeology, history, anthropology and many other fields recognize the importance of displaying their own scientific corpus in a museum context. This generated a present and evolving need for museological knowledge, which is how we came to the point where Johann Grässe made the well-known claim with which we opened this paper: that museology can be referred to as "a science" " or "a branch of science" "Fachwissenschaft). We have now come to the point where museology becomes not only a question of what-is-done, but also what-is-learned.

\footnotetext{
${ }^{31}$ GREENHILL, Museums and the Shaping of Knowledge..., p. 167.

32 Cf. POULOT, Dominique. The Birth of Heritage: 'le moment Guizot'. In: Oxford Art Journal, vol. 11, 1988, 2, pp. 40-56; ERIKSEN, Anne. From Antiquities to Heritage: Transformations of Cultural Memory. Oxford - New York: Berghahn, 2014.

${ }^{33}$ RATHGEBER, Georg. Aufbau der Niederländischen Kunstgeschichte und Museologie. Weißensee: G. F. Großmann, 1839; accessed 31 March 2019, https://books.google.rs/books?id=KbYnGwAACAAJ\&printsec=frontcover\&hl=sr\&source $=$ gbs_ge_summary_r\&cad $=0 \#_{\mathrm{v}}=$ onepage\&q\&f=false.

Truth be told, there is an even earlier appearance of the term: in Karl Ottfried Müller, Handbuch der Archäologie der Kunst (Manual of Archaeology), published in Breslau (Wrocław) in 1830. On page 284, Müller states that more can be found "on museology"("zur Museologie") in the book by Karl August Böttiger, Über Museen und Antikensammlungen: eine archäologische Vorlesung (Leipzig 1808), but there is no term museology in that publication, just museography. See also: WALZ, Markus. The German voice in the "Babelian tale of museology and museography": creation and use of terms for museum science in Germany. In: Museologica Brunensia, vol. 7, 2018, 2, pp. 5-18. ${ }^{34}$ In that sense, one should also mention engagements and research by German art historian and archaeologist Johann Joachim Winckelmann (1717-768).

${ }^{35}$ Cf. PREZIOSI, Donald. Art History and Museology. Rendering the Visible Legible. In: MACDONALD, Sharon (ed.) A Companion to Museum Studies. Malden, MA - Oxford: Blackwell Publishing, 2006, pp. 50-63.

${ }^{36}$ TEATHER, Museology and its traditions..., p. 2.

${ }^{37}$ MENSCH, Towards a methodology of museology..., p. 8.
} 
However, linguistic differences, such as those between "science" and "Wissenschaft", are not irrelevant in this case. Let us note, as did the perceptive contemporary scholar Bas van Bommel, that "the concept of 'science' never took on the comprehensive and pretentious meaning that the term 'Wissenschaft' obtained in Germany”. Among other things, here we can observe a root problem in the terminological differences between continental term museologie and its Anglo-Saxon equivalent museum studies. On the other hand, let us also bear in mind the following observation by the same author: "Without a doubt, the most influential concept in German university history is that of the 'unity of teaching and research' [Einheit von Lehre und Forschung]. From the late nineteenth century onwards, university foundations and reforms both in and outside of Europe have been inspired by the - originally German - idea that universities should not only aim at transmitting knowledge by means of education, but also at increasing it by way of scientific research". ${ }^{38}$ In other words, in order to determine the beginnings of museology as an academic discipline, we must ask ourselves what is its place in the context of the unity of teaching and research.

As we will see soon, the correlation between museology and museums themselves (as fields of research) is inseparable from the beginnings of museology as a modern academic discipline. But first, let us note that the issue of becoming an academic discipline is of great importance for a branch of knowledge. Taking our lead from Jacques Le Goff, who suggested that "it would not be an exaggeration to say that the teaching of history marked its birth as a branch of learning" 39 , we can say that museology became a scientific discipline precisely from the moment when it began to be taught as a distinct subject. As has been noted in the philosophy of science, for specialist knowledge (based on accumulated experience in a particular field) to become a scientific discipline, it is necessary to establish theoretical frameworks and for these to be disseminated through the educational process. Theoretical frameworks allow a unified view of the diverse elements of knowledge ${ }^{40}$ and the educational process transmits the current measure of knowledge, but also critically re-examines it.

In an academic context, museology began as a technique for creating museum displays pertaining to specific scientific disciplines. The first major initiative in museological education could be traced back to 1856, when the Spanish Government founded the Escuela Superior de Diplomatica in Madrid as an institution to train archivists, librarians and other professionals in charge of national heritage ${ }^{41}$. L'Ecole du Louvre, a higher education institution, was founded in Paris in 1882 with the aim of training researchers in the fields of archaeology, history of art, anthropology and classical languages, using the collections of the famous museum. However, it was not until 1927 that the first course in museography was held at this school. ${ }^{42}$

In the meantime, museology could be encountered in various contexts, as evidenced, for example, by the invitation to the first International Congress of Entomology in Europe in

\footnotetext{
${ }^{38}$ BOMMEL, Bas van. Between 'Bildung' and 'Wissenschaft': The 19th-Century German Ideal of Scientific Education. In: European History Online, Mainz: Leibniz Institute of European History (IEG), 14 December 2015. Accessed 31 March 2019, http://www.ieg-ego.eu/bommelb-2015-en URN: urn:nbn:de:0159-2015120917 [2019-01-02]. ${ }^{39}$ LE GOFF, Jacques. Faut-il vraiment découper l'histoire en tranches? [Must We Divide History Into Periods?] Original: "l'enseignement constitue en effet la pierre de touche de l'histoire comme connaissance", Paris: Éditions du Seuil, 2014, p.16. English edition translated by Malcolm DeBevoise, New York: Columbia University Press, 2015, p. 4.

${ }^{40}$ ROSENBERG, Alex. Philosophy of Science: A Contemporary Introduction. London and New York: Routledge, 2012, p. 116.

${ }^{41}$ LORENTE, Jesús-Pedro. The development of museum studies in universities: from technical training to critical museology. In: Museum Management and Curatorship, vol. 3, 2012, 27, pp. 238-239.

42 "Ecole du Louvre, historie", accessed 31 March 2019, http://www.ecoledulouvre.fr/ecole-louvre/histoire.
} 
1909 ${ }^{43}$. Almost at the same time, American museums began to hold curatorial courses ${ }^{44}$ and anthropologist Roland B. Dixon recognized museology as the term adequate for "a mere description and classification of ancient remains left by past ages". ${ }^{45}$ After the Great War, George Sarton (one of the originators of the field of history of science), in his preliminarily introduction to the history and philosophy of science, placed museology in a group of educational sciences whose goal is to methodically impart and diffuse knowledge. ${ }^{46}$ At the same time, at Masaryk University in Brno, museology lectures led by Jaroslav Helfert were initiated in $1921^{47}$, while at Harvard University, the art historian Prof. Paul J. Sachs, began to teach a course entitled Museum Work and Museum Problems. ${ }^{48}$

In the post WWII Cold War era, under the influence of the L'Ecole du Louvre and the museography course given by Germain Bazin, the Western world developed a particular route of "museum science", centred around the museum object and organization of museum works. ${ }^{49}$ On the other side of the Iron Curtain, in 1963, Jan Jelinek, an anthropologist and curator of the Moravian Museum, (re)established a museology department at Masaryk University (now known as Jan E. Purkyne University). Debates about museology featured in academic discussions on both sides of the Iron Curtain. ${ }^{50}$ At the University of Leicester (UK) in 1966, a Department of Museum Studies was founded by Raymond H. Singleton. Allegedly, the name museum studies was chosen instead of museology "because he detested the endless debates on the theory of museology which his colleagues at central and eastern European universities were engaged in", and wished to give priority to providing "practical training to graduates from any discipline who wished to work in a museum". 51

The founding, in 1977, of ICOFOM - the International Committee for Museology within the International Council of Museums (ICOM) - created a space for geographically (and maybe ideologically) divided museologists to discuss museological topics. ${ }^{52}$ Also in 1977, the Department of Archaeology and Museology was established in Brno, and in the mid-nineties the museology became a special section within this department. Alongside its regular university

\footnotetext{
${ }^{43}$ The invitation to this event read: "The first International Congress of Entomology will be held on August 1-16, 1910, at Brussels, during the International Exposition, which will be taking place there at that time. The subjects to be brought before the general or sectional meetings will comprise systematics, nomenclature, anatomy, physiology, psychology, ontogeny, phylogeny, ecology, mimicry, etiology, bionomy, paleontology, zoo geography, museology, medical and economic entomology". In Science, New Series, 30(769), 24 September 1909, p. 404.

${ }^{44}$ LORENTE, The development of museum studies in universities..., p. 239.

45 "If archeology is more than a mere description and classification of ancient remains left by past ages (and this could assuredly be only its technical foundation, which may be described under the term 'museology')...". DIXON, Some Aspects of North American Archeology..., p. 573.

${ }^{46}$ SARTON, Introduction to the History..., p. 29.

${ }^{47}$ DOLÁK, Jan. Czech and Slovak museology, current status and the future of this branch of science. In: Nordisk Museologi, 2007, 2, pp. 99-186.

${ }^{48}$ DUNCAN, Sally Anne and Andrew MCCLELLAN. The Art of Curating: Paul J. Sachs and the Museum Course at Harvard. Los Angeles: Getty Research Institute, 2018.

${ }^{49}$ BAZIN, Germain. Museologie: cours de Mr Germain Bazin. Paris: Ecole du Louvre, 1950.

${ }^{50}$ These discussions are very well elaborated in GLUZINSKI, Wojciech. U podstaw muzeologii. Warszawa: PWN, 1980. See also, STRÁNSKÝ, Pojam muzeologije..., pp. 17-28. There is a valuable overview of Russian and Soviet museological experience in ŠULEPOVA, Èleonora Aleksandrovna (ed.) Mužeevedčeskaja mysl' v Rossii XVIII-XX vekov: Sbornike dokumentov i materialov [Museological Thought in Russia eighteenth-twentieth centuries. Proceedings of Documents and Materials]. Moskva: Ėterna, 2010. [In Russian]

${ }^{51}$ LORENTE, The development of museum studies in universities, p. 240.

${ }^{52}$ In this regard, it is worth noting the importance of the professional associations and journals that preceded the ICOM. Cf. STRÁNSKÝ, Pojam muzeologije..., pp. 7-8.
} 
courses, the school in Brno became known for organising museological seminars, which in 1986/87, with the support of UNESCO, grew to become the International Summer School of Museology. ${ }^{53}$ In same period, after the spark lighted during the seventies, "new museology" erupted onto the scene. This ranged from (in its significant form) the well-founded conjunction of the Brno School and George-Henri Rivière concepts, to more liberal (and even frivolous) interpretations of museum policies. ${ }^{54}$ From there, the contemporary concept of museum studies was developed as a "cross-disciplinary dialogue about museums". ${ }^{55}$

The last two decades of the twentieth century brought further changes to museological world, with two great "explosions" - a museum and a memory boom, which brought to the fore questions of identity and heritage, and, from there, the relation of modern man with his past. Museology had something to say about this, so one of the specific results of these movements (sprung from previously tilled soil) was the founding of numerous university seminars on museology or museum studies at the global level, as well as the expansion of professional and academic journals and other literature. ${ }^{56}$ Thus, by 1997, the Croatian Professor of Museology, Ivo Maroević, could observe that "Today, museology is an academic discipline with regular university graduate study programmes in many counties... This is a great difference in comparison with position of museology some twenty years ago". ${ }^{57}$

It was through this route that, twenty years later, we could arrive at the five contemporary definitions of museology stated earlier, which testify more to the rich variety of approaches than to the unique object of research. ${ }^{58}$

\section{Conclusion: The name of the Muses}

Even in the recent past, the idea of museology as a scientific discipline was considered to be something of a "Continental eccentricity". ${ }^{9}$ There is a famous statement, often attributed to Richard Feynman, that the philosophy of science is about as useful to scientists as ornithology is to birds. As we might observe, birds do not receive much benefit from ornithology, nor from physics, nor from any other science or philosophy. The only one who benefits is man. Similarly, it could be said that museums have reaped as many benefits from contemporary museology as birds have from ornithology. But here, at the end of paper, it seems that we have forgotten an important "beginning".

Museology owes its name, as do museum and music, to the daughters of Power (Zeus) and Memory (Mnemosyne) - that is, to the Muses. But, how did the Muses get their name? As one famous encyclopaedia teaches us: "They are said to be called Muses, from a Greek word meaning to explain mysteries, Múєı , because they taught men very curious and important things

\footnotetext{
${ }^{53}$ STRÁNSKÝ, Zbyněk. The Department of Museology, Faculty of Arts, Masaryk University of Brno and the questions of defining a profile of the museology curriculum. In: ICOFOM Study Series, 1993, 22, p.127.

${ }^{54}$ Regarding the popularity of inventions of "new" in traditional disciplines, see BURKE, Peter. What is Cultural History? Cambridge: Polity, 2008, pp. 77-101.

${ }_{55}^{5}$ MACDONALD, Sharon. Expanding Museum Studies: An Introduction. In: MACDONALD, Sharon (ed.) $A$ Companion to Museum Studies. Malden, MA - Oxford: Blackwell Publishing, 2006, p. 1.

${ }^{56}$ Cf. LORENTE, The development of museum studies in universities..., pp. 237-252.

${ }^{57}$ MAROEVIĆ, Ivo. Museology in the Future World. In: STRÁNSKÝ, Zbyněk (ed.) Proceedings of the international symposium 'Museology for Tomorrow's world”. Munich: Verlag Dr. Christian Mueller-Straten, 1997, p. 21.

${ }^{58}$ DESVALLÉES and MAIRESSE, Key Concepts of Museology..., pp. 53-56. See also STARN, Randolph. A Historian's Brief Guide to New Museum Studies. In: The American Historical Review, 2005, 110, 1, pp. 68-98.

${ }^{59}$ SOFKA, Vinoš. My adventurous life with ICOFOM, museology, museologists and anti-museologists, giving special reference to ICOFOM Study Series. Paris: ICOFOM, 1995, p. 8.
} 
that are beyond the reach of the vulgar". ${ }^{60}$ Through the various "beginnings" of museology we explored, can we take this idea - the need for a non-vulgar articulation of the world - as a conclusion? We have seen how museology changed and how it dodged various academic frames and classifications. We talked about museology as knowledge about the systematization of collections, as the art of museum organization, and as the theorisation of the relationship between man and his reality. In the years since the term was first coined, scientific paradigms changed, "revolutionary" sciences became traditional, and academic knowledge became an instrument of liberation, then an ideology, then merchandise. And for all that time, museology was often perceived as a discipline that was only just beginning.

Having all this in mind, it could be argued in the end that throughout its history, the idea of museology has more or less successfully managed to avoid vulgar traps of scientism. Instead, within the comprehensive corpus of science and its heritage, museology remains a provoking and elusive discipline that constantly reinvents its own beginnings.

\section{References}

ANANIEV, Vitalij Gennadievič, METELKIN, Evgenij Nikolaevič (2015). I. G. T. fon Grasse i ego rol' v razvitii muzeologii, vtoroj poloviny XIX v [I. G. T. fon Grasse and its roll in the development of museology in the second half of nineteenth century]. In: Voprosy muzeologii, vol. 12, 2, pp. 17-21 [In Russian]. ISSN 2219-6269.

AQUILINA, Janick Daniel (2011). The Babelian Tale of Museology and Museography: a history in words. In: Museology: International Scientific Eletronic Journal, 6, pp. 1-20. ISSN 23072334.

BAZIN, Germain (1950). Museologie: cours de Mr Germain Bazin. Paris: Ecole du Louvre. [No ISBN]

BOMMEL, Bas van (2015). Between 'Bildung' and 'Wissenschaft': The 19th-Century German Ideal of Scientific Education. In: European History Online (EGO). Mainz: Leibniz Institute of European History (IEG), 2015-12-14. URL: http://www.ieg-ego.eu/bommelb-2015-en URN: urn:nbn:de:0159-2015120917 [2019-01-02].

BURKE, Peter (2008). What is Cultural History? Cambridge: Polity. ISBN 0745644090.

DESVALLÉES, André and MAIRESSE, François (2005). Sur la muséologie. In: Culture \& Musées, 6, pp. 131-155. ISSN 2111-4528.

DESVALLÉES, André and MAIRESSE, François (eds.) (2010). Key Concepts of Museology. Paris: Armand Colin. ISBN 978-2-200-25398-1.

DIXON, Roland B. (1913). Some Aspects of North American Archeology. In: American Anthropologist, New Series, vol.15, 4, pp. 573-574.

DOLÁK, Jan (2007). Czech and Slovak museology, current status and the future of this branch of science. In: Nordisk Museologi, 2:99-186. ISSN 2002-0503.

DUNCAN, Sally Anne and MCCLELLAN, Andrew (2018). The Art of Curating: Paul J. Sachs and the Museum Course at Harvard. Los Angeles: Getty Research Institute. ISBN-13 9781606065693 / ISBN-10 1606065696.

\footnotetext{
${ }^{60}$ LOUIS, chevalier de Jaucourt. Muses. In: The Encyclopedia of Diderot \& d'Alembert Collaborative Translation Project. Translated by Emily K. Wu. Ann Arbor: Michigan Publishing, University of Michigan Library, 2015. Accessed 31 March 2019, http://hdl.handle.net/2027/spo.did2222.0002.871. Trans. of "Muses", Encyclopédie ou Dictionnaire raisonné des sciences, des arts et des métiers, vol. 10. Paris, 1765.
} 
ERIKSEN, Anne (2014). From Antiquities to Heritage: Transformations of Cultural Memory. Oxford - New York: Berghahn. ISBN-10 1782382984 / ISBN-13 978-1782382980.

GADAMER, Hans-Georg (2000). The Beginning of Philosophy. London: Bloomsbury Academic. ISBN 9781474294478.

GLUZINSKI, Wojciech (1980). U podstaw muzeologii. Warszawa: PWN. ISBN 83-01-02103-9.

GOB, André, DROUGUET, Noémie (2014). La muséologie. Histoire, développements, enjeux actuels. 4e édition. Paris: Édition Format Kindle de Armand Colin. ISBN-10 2200291183 / ISBN13 978-2200291181.

GOEING, Anja-Silvia (2014).Mapping curiosity: Kaspar Friedrich Jencquel's Recommendations for Visits of Cabinets in Europe (1727), https://curiositas.org/mapping-curiosity-kasparfriedrich-jencquels-recommendations-for-visits-of-cabinets-in-europe-1727

GRÄSSE, Johann Georg Theodor (1883). Die Musologie as Fachwissenschaft. In: Zeitschrift für Museologie und Antiquitätenkunde sowie verwandte Wissenschaften, 15, p. 1.

GREENHILL, Eileen Hooper (1992). Museums and the Shaping of Knowledge. London - New York: Routledge. ISBN-13 978-0415070317 / ISBN-10 0415070317.

HAXHIRAJ, Marinela (2016). Ulisse Aldrovandi. Il museografo. Bologna: Bononia Univerity Press. ISBN-10 8869231852, ISBN-13 978-8869231858.

IMPEY, Oliver and MACGREGOR, Arthur (eds.) (1985). The Origins of Museums: The Cabinet of Curiosities in Sixteenth and Seventeenth Century Europe. Oxford: University Press. ISBN-10 1842321323 / ISBN-13 978-1842321324.

LE GOFF, Jacques (2014). Faut-il vraiment découper l'histoire en tranches? Paris: Éditions du Seuil. ISBN 978-2-02-110605-3.

LOCHER, Hubert et al. (2004). (eds.) Museen als Medien - Medien in Museen. Perspektiven der Museologie. Munchen: Müller-Straten, ISBN 9783932704789.

LORENTE, Jesús-Pedro (2012). The development of museum studies in universities: from technical training to critical museology. In: Museum Management and Curatorship, vol. 27, 3, pp. 237-252. ISSN 1872-9185,

LOUIS, chevalier de Jaucourt (1765). Muses. In: The Encyclopedia of Diderot \& d'Alembert Collaborative Translation Project. Translated by Emily K. Wu. Ann Arbor: Michigan Publishing, University of MichiganLibrary, 2015. < http://hdl.handle.net/2027/spo.did2222.0002.871>. Trans. of "Muses", Encyclopédie ou Dictionnaire raisonné des sciences, des arts et des métiers, vol. 10. Paris, 1765.

MACDONALD, Sharon (2006) (ed.). A Companion to Museum Studies. Malden, MA - Oxford: Blackwell Publishing. ISBN 978-1-405-10839-3

MAROEVIĆ, Ivo (1997). Museology in the Future World. In: STRÁNSKÝ, Zbyněk (ed.) Proceedings of the international symposium "Museology for Tomorrow's world". Munich: Verlag Dr. Christian Mueller-Straten, pp 21-29. ISBN 3932704576, 9783932704574.

MAROEVIĆ, Ivo (1998). Introduction to Museology: The European Approach. Munich: Vlg. Dr. C. Müller-Straten. ISBN 3-932704-52-5.

MEADOW, M. A. (ed.) (2013). The First Treatise on Museums. Samuel Quiccheberg's Inscriptiones, 1565. Los Angeles: Getty. ISBN 978-1606061497.

MENSCH, Peter van (1992). Towards a methodology of museology. Zagreb: University of Zagreb. PhD thesis.

MURRAY, David (1904). Museums, their history and their use. Glasgow: J. MacLehose.

NEICKELIUS, Caspar Friedrich (1727). Museographia oder Anleitung zum rechten Begriff und 
nützlicher Anlegung der Mvseorvm Oder. Raritäten-Kammern. Leipzig: Hubert.

POULOT, Dominique (1988). The Birth of Heritage: 'le moment Guizot'. In: Oxford Art Journal, vol. 11, 2, pp. 40-56. ISSN 0142-6540.

QUICCHEBERG, Samuel (1565). Inscriptiones vel tituli Theatri amplissimi, complectentis rerum universitatis singulas materias et imagines eximias etc. Monachii: Adamus Berg.

RATHGEBER, Georg (1839). Aufbau der Niederländischen Kunstgeschichte und Museologie. Weißensee: G. F. Großmann.

ROMANO, Marco, Richard L. CIFELLI, Gian Battista VAI (2015). Natural history: first museologist's legacy. In: Nature, 517, p. 271. ISSN 1476-4687.

ROSENBERG, Alex (2012). Philosophy of Science: A Contemporary Introduction. London and New York: Routledge. ISBN-13 978-0415891776 / ISBN-10: 9780415891776

SARTON, George (1921). Introduction to the History and Philosophy of Science (Preliminary Note). In: Isis, vol. 4, 1, pp. 23-31.

SCHLOSSER, Julius von (1908). Die Kunst-und Wunderkammern der Spätrenaissance: ein Beitrag zur Geschichte des Sammelwesens. Leipzig: Klinkhardt \& Biermann.

SCHNEIDER, Evzen (1977). La voie du musée, exposition au musée Morave. In: Museum, vol. 29, 4, pp. 183-191. ISSN 1755-5825.

SCIENCE (1909), New Series, 30, 769, p. 404, Sep. 24. ISSN 00368075.

SMEDS, Kerstin (2018). Museum science? In: Nordisk Museologi, 1, pp. 154-156. ISSN 20020503.

SOFKA, Vinoš (1995). My adventurous life with ICOFOM, museology, museologists and anti-museologists, giving special reference to ICOFOM Study Series. Paris: ICOFOM.

STARN, Randolph (2005). A Historian's Brief Guide to New Museum Studies. In: The American Historical Review, 110, 1, pp. 68-98. ISSN 0002-8762.

ŠOLA, Tomislav (1982). Towards a possible definition of museology. Paper presented at the ICOFOM Annual Conference, Paris: ICOFOM (accesed 12 April 2019, http:// www.heritology.com/A_contribution_to_a_possible_definition_of_Museology_-_by_ Tomislav_Sola.pdf

STRÁNSKÝ, Zbynek (1970). Pojam muzeologije. In: Muzeologija, 8, pp. 2-39. [In CroatoSerbian]. ISSN 1849-0913.

STRÁNSKÝ, Zbyněk (1993). The Department of Museology, Faculty of Arts, Masaryk University of Brno and the questions of defining a profile of the museology curriculum. In: ICOFOM Study Series, 22, pp. 127-131. ISSN 2309-1290.

ŠULEPOVA, Èleonora Aleksandrovna (2010) (ed.). Muzeeveď̌eskaja mysl'v Rossii XVIII-XX vekov: Sbornik dokumentov i materialov. [Museological Thought in Russia eighteenth to twentieth centuries. Proceedings of Documents and Materials]. Moskva: Èterna. [In Russian] ISBN 978-5-480-00223-2.

TEATHER, Lynne (1983). Museology and its traditions: The British experience, 1845-1945. University of Leicester. PhD thesis.

VALENTINI, Michael Bernhard (1704). Museum Museorum, oder vollständige Schau-Bühne aller Materialien und Specereyen, nebst deren natürlichen Beschreibung... Franckfurt am Mayn: In Verlegung Johann David Zunners.

WAIDACHER, Friedrich (1999). Handbuch der Allgemeinen Museologie. Wien: Böhlau. ISBN 9783205991304.

WALZ, Markus (2018). The German voice in the "Babelian tale of museology and museography": 